\title{
PERANCANGAN KARAKTER WAYANG TETUKA \\ UNTUK LANJUTAN CERITA SAAT KE LUAR DARI KAWAH CANDRADIMUKA
}

\author{
Febrianto Saptodewo \\ Program Studi Desain Komunikasi Visual, \\ Fakultas Bahasa dan Seni Universitas Indraprasta PGRI \\ Jl. Nangka 58 Tanjung Barat, Jakarta Selatan, 12530 \\ febrianto.saptodewo@gmail.com
}

\begin{abstract}
Abstrak
Diceritakan dalam lakon pewayangan lahirnya Gatotkaca, yang pada saat ia kecil bernama Tetuka. Di masa tersebut Tetuka kecil dimasukkan ke dalam Kawah Candradimuka untuk digodok dan ditempa hingga akhirnya ia ke luar dari dalam kawah telah berubah wujud menjadi seorang pemuda gagah perkasa. Sosok pemuda yang baru ke luar dari kawah inilah yang dirancang karakter visualnya berdasarkan bentuk wayang Purwa hingga melengkapi perancangan sebelumnya.
\end{abstract}

Kata Kunci: Tetuka, Kawah Candradimuka, Wayang, Karakter, Perancangan

\begin{abstract}
Told stories of the birth of Gatotkaca, who at the time called it Tetuka. Tetuka at that time included a small crater in the brewing and forged until it comes out of the Candradimuka crater has been transformed into a young man mighty. The figure of a young man coming out of the Candradimuka crater is designed based on the visual character wayang Purwa to complete the planning in advance.
\end{abstract}

Keywords: Tetuka, Candradimuka Crater, Shadow Puppet, Character, Design 


\section{PENDAHULUAN}

Nilai estetis selain terdiri dari keindahan sebagai nilai yang positif kini dianggap pula meliputi nilai yang negatif. Hal yang menunjukkan nilai negatif itu ialah kejelekan (ugliness). Kejelekan tidaklah berarti kosongnya atau kurangnya ciri-ciri yang membuat benda tersebut indah, melainkan menunjukan pada ciri-ciri yang sangat bertentangan sepenuhnya dengan kualitas yang indah itu. Dalam kecenderungan seni dewasa ini, keindahan tidak lagi merupakan tujuan yang paling penting dari seni. Sebagian seniman menganggap lebih penting menggoncangkan publik daripada menyenangkan orang dengan karya seni mereka. Guncangan perasaan dan kejutan batin itu dapat terjadi, dengan melalui keindahan maupun kejelekan. Oleh karena itu, kini keindahan dan kejelekan sebagai nilai estetis yang positif dan yang negatif menjadi sasaran penelaahan dari estetika filsafati. Nilai estetika pada umumnya kini diartikan sebagai kemampuan dari suatu benda untuk menimbulkan suatu pengalaman estetis, (Kartika, 2007:14-15).

Tingginya nilai estetika pada wayang di antaranya bisa dilihat dari seni ukir wayang (tatah sungging). Pembuatan setiap tokoh wayang, memiliki ciri dan watak tersendiri. Keragaman bentuk wayang itu tidak menggambarkan manusia secara wajar, tetapi dari watak berbagai tokohnya dalam dunia pewayangan. Setiap wayang melukiskan secara wajar, akan tetapi watak berbagai tokoh dalam dunia perwayangan. Setiap wayang melukiskan watak tertentu dan dalam keadaan batin tertentu. Setiap pola bentuk wayang memiliki wanda, ungkapan watak atau ekspresi batin. Wanda wayang Kresna misalnya, berbeda dengan wanda Arjuna. Sementara wanda Arjuna beraneka ragam pula jenisnya, seperti wanda kinanthi, kanyut, mangu dan sebagainya. Setiap wanda melukiskan ekspresi keadaan batin tertentu dalam diri Arjuna. Karena itu, jumlah wayang kulit yang semestinya cukup 200 biji dalam satu kotak, karena adanya wanda tersebut jumlahnya bisa menjadi 650 biji lebih.

Dari data harian Kompas 28 Maret 2009, akibat kecanggihan teknologi membuat batas budaya asing dengan budaya asli semakin tipis. Kesenian lokal terus tersisih karena masyarakat kian jauh dari kegiatan seni. Oleh karena itu, tidak heran jika generasi muda sekarang semakin asing dengan kesenian dari daerah mereka sendiri. Fenomena ini terungkap dalam jajak pendapat Kompas.

Perkembangan teknologi dengan segala kemudahan yang ditawarkan, janganlah diasumsi bahwa teknologi merupakan suatu hal yang dapat menyingkirkan kebudayaan lama. Dengan teknologi yang semakin berkembang tersebut dapat disikapi secara positif dan berpikiran terbuka, maka teknologi tersebut akan membantu pelestarian dan pengembangan budaya lama. Penggabungan teknologi dengan kebudayaan akan meningkatkan kualitas kebudayaan, bahkan akan memungkinkan tumbuhnya kebudayaan-kebudayaan baru. Penggabungan penggunaan teknologi komputer dengan konsep Wayang Purwa, dirancanglah transformasi tokoh karakter visual Tetuka. Hasil akhir perancangan tersebut berupa data komputer yang bisa diaplikasikan dalam bentuk cetak dan cutting maupun ditransfer ke media kulit melalui teknik tatah dan sungging berdasarkan rancangan karakter Tetuka tersebut.

Joedawinata pada desertasinya (2012), produk dari sebuah kebudayaan adalah desain sebagai hasil interaksi dari kebudayaan manusia, karakteristik manusia seutuhnya dengan seperangkat sistem kebutuhannya, karakteristik 
ekologi alam kawasan, serta eksplorasi dari unsur dan sistem desain visual baik yang tangible maupun yang intangible, yang hidup dan terdapat di komunitas masyarakat di kawasan tertentu pada periode waktu tertentu (dalam Saptodewo, 2016: 230).

Dengan perancangan karakter visual Tetuka akan menjebatani hal-hal yang sifatnya fiksional, suatu hal yang tidak dapat dilakukan pada kehidupan nyata yang akan menjadi suatu daya tarik tersendiri dari pengembangan lakon Tetuka nantinya.

Narasi visual berupa relief pada dinding candi yang tersebar di Indonesia merupakan bentuk storytelling, dimana karakternya digambarkan secara realis dan mencerminkan kehidupan sosial saat itu. Beberapa relief juga menggambarkan pemujaan kepada Raja dan Tuhan dengan berbagai gaya dan simbolisasi. Dalam perkembangannya, karakter desain kurang diberikan perhatian yang memadai. Karakter hanya identik dengan artefak visual tanpa diperkaya kajian mendalam mengenai hal-hal yang berkaitan dengan pengembangan karakter diluar aspek visual. Padahal proses "menghidupkan" suatu karakter harus mencakup berbagai aspek secara menyeluruh seperti visual, psikologis, simbol, ideologi, dan sebagainya (Saptodewo dan Hadiprawiro, 2016: 71).

Acuan perancangan sosok karakter pada tampilan, kepribadian tokoh karakter yang sesuai dengan cerita, dan kemampuan rancangan karakter tersebut dalam mempresentasikan dalam bentuk visualnya.

Beberapa komponen penting dalam mempertimbangkan perancangan karakter visual adalah gender, ras, keunikan pada penampilannya, menjaga kesederhanaan dalam bentuk yang rumit, dan karakter yang mudah diingat dan diidentifikasi saat melihatnya.
Secara umum dalam karakter wayang, kebanyakan hanya warna muka wayang saja yang memiliki makna simbolis. Terkadang warna-warna yang digunakan memiliki lambang tertentu sesuai dengan karakter tokohnya, tidak selalu warna muka tersebut melambangkan hal yang sama. Warna muka dan badan wayang bermacam-macam. Yakni merah, hitam, putih, hijau, biru, dan prada. Warna hitam mempunyai makna simbolis kesaktian dan kemapanan hidup, warna putih melambangkan sifat kesucian dan kehalusan budi, warna merah elambangkan sifat angkara murka dan pemberani, warna kuning melembangkan sifat ketampanan dan keluhuran. Warna wajah serta tubuh wayang pada wayang kulit memang mempunyai arti simbolis, akan tetapi tidak ada ketentuan umum yang tetap di sini, (Purbasari, 2012:7).

Penggambaran karakter Tetuka disesuaikan dengan wataknya dalam cerita dianalisis segi fisiknya dan psikisnya yang masih setengah manusia dan setengah raksasa. Psikis dari karakter Tetuka yang berlatar keturunan dari ayahnya, Bima yang merupakan dari bangsa manusia, serta Dewi Arimbi yang merupakan putri dari kerajaan bangsa raksasa, maka fisik Tetuka bertubuh lebih besar dari manusia seusianya dan bertarik layaknya raksasa namun tidak berwajah kasar. Dilihat dari segi sosiologinya, Tetuka hidup dikalangan kerajaan yang nantinya berlanjut pada penempaan hidup dalam Kawah Candradimuka hingga ia menjadi seorang ksatria.

Sebuah desain karakter yang baik memberikan pemberian detil. Keunikan akan tercipta pada pemberian detil pada karakter. Menurut Kaelola, (2010: 188) . Sewaktu lahir kepala jabang Tetuka konon mirip dengan buli-buli atau kendi. Keunikan tersebut akan berubah menjadi membingungkan dan menyusahkan 
apabila terlalu banyak detil yang ditambahkan.

Meskipun banyak sekali karakterkarakter yang telah sering dilihat baik melalui film animasi, komik, pagelaran wayang maupun iklan terlihat sederhana, tetapi biasanya kesederhanaan tersebut tercipta melalui proses riset dan desain yang panjang. Dipastikan akan berpikir keras untuk mendesain karakter tersebut seperti apa yang akan dirancang, bukan hanya sesuai dengan imajinasi si perancang saja, tapi juga menarik bagi penonton (Saptodewo dan Hadiprawiro, 2016: 71-72).

\section{PEMBAHASAN}

Dibuat dengan kekaguman adalah dalam membuat bentuk wayang lalu menjadi mudah dimengerti oleh setiap orang sampai semua merasa senang. Bila melihat wayang Kresna, Janaka, Gatotkaca, Werkudara, serta leluconnya Semar, Gareng, Petruk, di saat wayang ke luar dalam lakon apa saja, apabila karakter tersebut sedang mendapat kesusahan para pamirsa juga akan ikut merasa susah, sedangkan kalau sedang mendapat kemuliaan atau mendapat keanugrahan, para pamirsa akan ikut senang, rasanya para pamirsa semua ikut mendapat kemuliaan dan keberuntungan. Sampai begitu dalam merasuk ke dalam hati sanubari manusia. Jadi sudah jelas kalau wayang itu tidak menggambarkan bentuk belaka, di sana hanya menunjukkan watak tinggi rendahnya budi, yang kasar serta yang halus.

Melanjutkan perancangan-perancangan karakter Tetuka sebelumnya seperti yang masih menggunakan perangkat komputer dengan aplikasi software Adobe Illustrator CS3. Dengan berdasarkan acuan dari literatur, maka Tetuka bermata telengan dan berhidung dempak merupakan perpaduan ciri fisik wayang dari ayahnya yaitu Bima dan setelah Tetuka menjadi Gatotkaca. Berbeda dengan raksasa pada umumnya karena ia adalah keturunan ibunya yang dari bangsa raksasa kerajaaan Pringgadani maka ia berbudi pekerti baik. Karakter Tetuka saat ini setelah ia ke luar dari Kawah Candradimuka adalah seorang ksatria yang perkasa setelah melalui penggeblengan dalam Kawah Candradimuka.

Kemampuan berperang dan sebagai pemimpin yang dewasa. Namun taring pada giginya yang menandakan bahwa ia adalah perpaduan dari bangsa manusia dengan bangsa raksasa masih ada pada fisik karakter tersebut. Di dalam cerita nantinya taring tersebut akan ditanggalkan, diceritakan dengan kehendak Dewa-Dewa, Tetuka itu dimasak sebagai bubur dan diisi dengan segala kesaktian; karena itu Tetuka yang nantinya Raden Gatotkaca berurat kawat, bertulang besi, berdarah gala-gala, akan dapat terbang di awan dan duduk di atas awan yang melintang seke luarnya dari Kawah Candradimuka. Kecepatan Tetuka pada saat terbang di awan sebagai kilat, liar sebagai halilintar (Hardjowirogo, 1968:137). Tetuka seke luarnya dari Kawah Candradimuka, kemudian bertarung dengan Patih Sekipu dan berhasil membunuhnya menggunakan gigitan taringnya. Kresna dan Pandawa saat itu datang menyusul ke kahyangan. Kresna kemudian memotong taring Tetuka dan menyuruhya berhenti menggunakan sifat-sifat kaum raksasa, (Kaelola, 2010:189-190).

Batara Guru raja kahyangan menghadiahkan seperangkat pakaian pusaka, yaitu Caping Basunanda, Kotang Antrakusuma, dan terompah Pandakacarma untuk dipakai Tetuka, yang sejak saat itu diganti namanya menjadi Gatotkaca. Dengan menggunakan pakaian pusaka tersebut, Gatotkaca mampu terbang secepat kilat menuju Kerajaan Trabelasuket dan 
membunuh Kalapracona, (Kaelola, 2010:189-190). Dari cerita tersebut dan acuan perancangan sebelumnya, maka rancangan karakter Tetuka saat ia ke luar dari Kawah Candradimuka menjadi dasar perancangan, selain itu bentuk dari wayang Gatotkaca juga menjadi pertimbangan bentuknya.

Beberapa tokoh pewayangan yang sebagai acuan pembentukkan tokoh Tetuka saat ia ke luar dari Kawah Candradimuka yaitu tokoh karakter Jagal Abilawa yang merupakan bentuk karakter samaran dari tokoh Bima ayah dari Tetuka, lalu tokoh Dewi Arimbi seorang putri dari kerajaan bangsa raksasa dan merupakan ibu dari Tetuka. Acuan perancangan berikutnya adalah tokoh Gatotkaca, karena merupakan transformasi akhir dari perancangan bentuk tokoh karakter Tetuka yang nantinya di dalam cerita berubah nama menjadi Gatotkaca setelah ia menerima pakaian pusaka, yaitu Caping terompah Pandakacarma dari Batara Guru.

Melengkapi transformasi rancangan tokoh Tetuka maka akan sedikit dibahas perancangan sebelumnya. Konsep perancangan awal yang telah dipublikasikan pada Jurnal Desain Vol. 01 No. 02 Jan-Apr 2014 yang berjudul "Perancangan Visualisasi Tokoh Wayang Bambang Tetuka" bahwa perancangan dibuat saat tokoh Tetuka masih bayi lengkap dengan tali pusar yang belum dapat terpotong.

Warna rias merah untuk wajah misalnya, sebagian besar menunjukkan sifat angkara murka, akan tetapi tokoh Yamadipati atau Setyaki yang memiliki warna rias muka merah bukanlah tokoh angkara murka. Jadi karakter wayang tidaklah ditentukan oleh warna rias muka saja, tetapi juga ditentukan oleh unsur lain, seperti misalnya bentuk (patron) wayang itu sendiri, (Purbasari, 2012:7).

Basunanda, Kotang Antrakusuma, dan
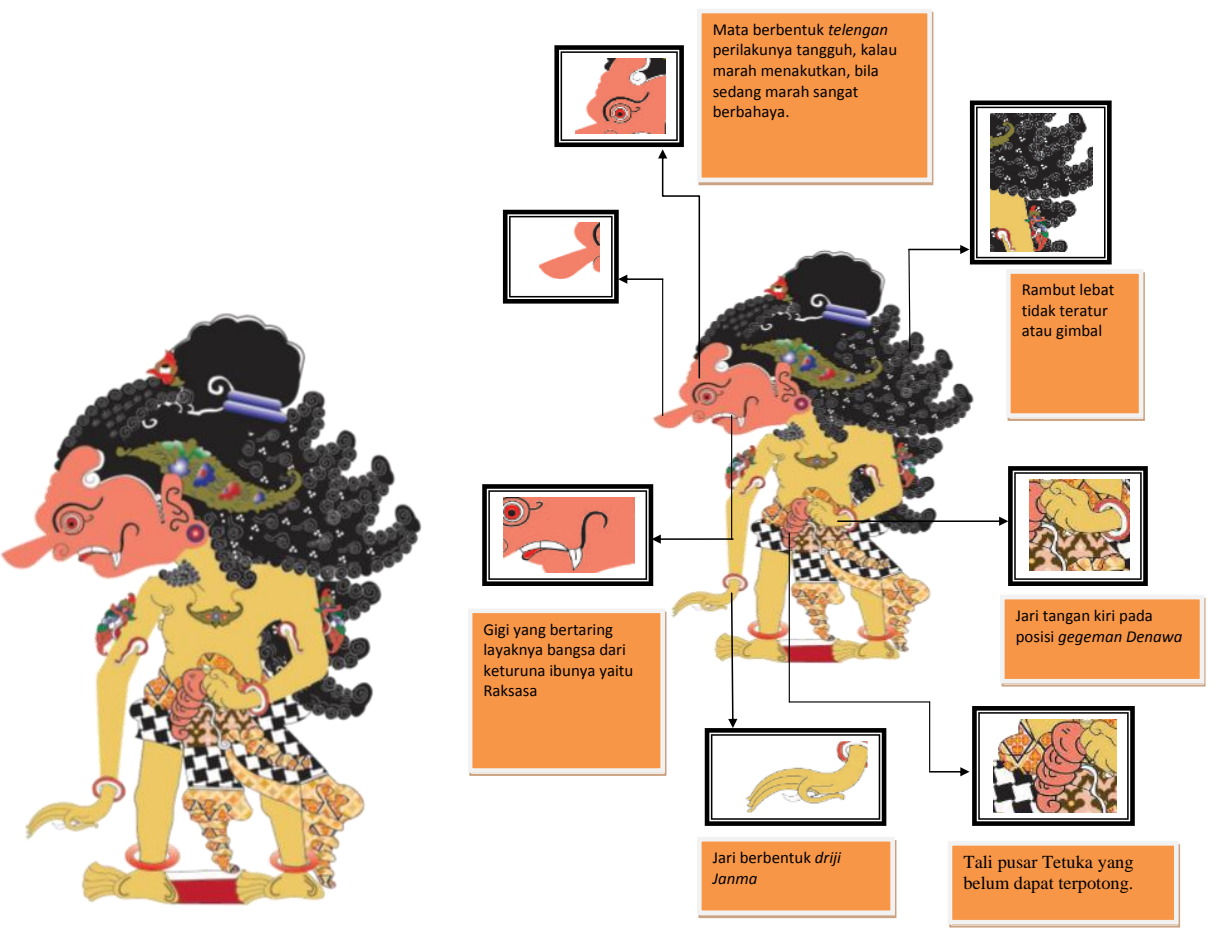

Gambar 1. Visual Bayi/Jabang Tetuka

(Sumber: F. Saptodewo) 
Dengan berdasarkan acuan dari pustaka, Tetuka digambarkan bermata telengan dan mempunyai hidung berbentuk dempak dengan warna rias muka merah muda layaknya bayi yang baru lahir. Berbeda dengan raksasa pada umumnya karena ia adalah keturunan bangsa raksasa Dengan rambut yang gimbal layaknya bangsa keturunan dari ibunya, Raksasa dan saat Bima muda saat ia menyamar menjadi Jagal Abilawa. Pada rancangan tokoh Tetuka pada saat bayi ini, lengkap dengan tali pusar yang belum terpotong. Dengan perbedaan bentuk dan ukuran dari wayang bayi maka karakter jabang Tetuka dapat lebih mudah dikenali.
Lalu dilanjutkan dengan konsep bentuk karakter Tetuka saat ia Balita, telah dipublikasikan pada Jurnal Desain Vol. 03 No. 01 September 2015 yang berjudul "Perancangan Bentuk Tokoh Wayang Tetuka Saat Balita", tidaklah jauh dari bentuk perancangan pada saat Tetuka masih bayi. Tetap dengan gigi taring karena merupakan masih adanya keturunan dari bangsa raksasa namun dari segi ukuran dan penampilan sedikit berbeda dari bentuk dan ukuran perancangan saat masih bayi. Masih berbasis dari perpaduan dari kedua orang tuanya dan bentuk dari bentuk bayi Tetuka, maka konsep perancangan Tetuka saat balita adalah sebagai berikut:
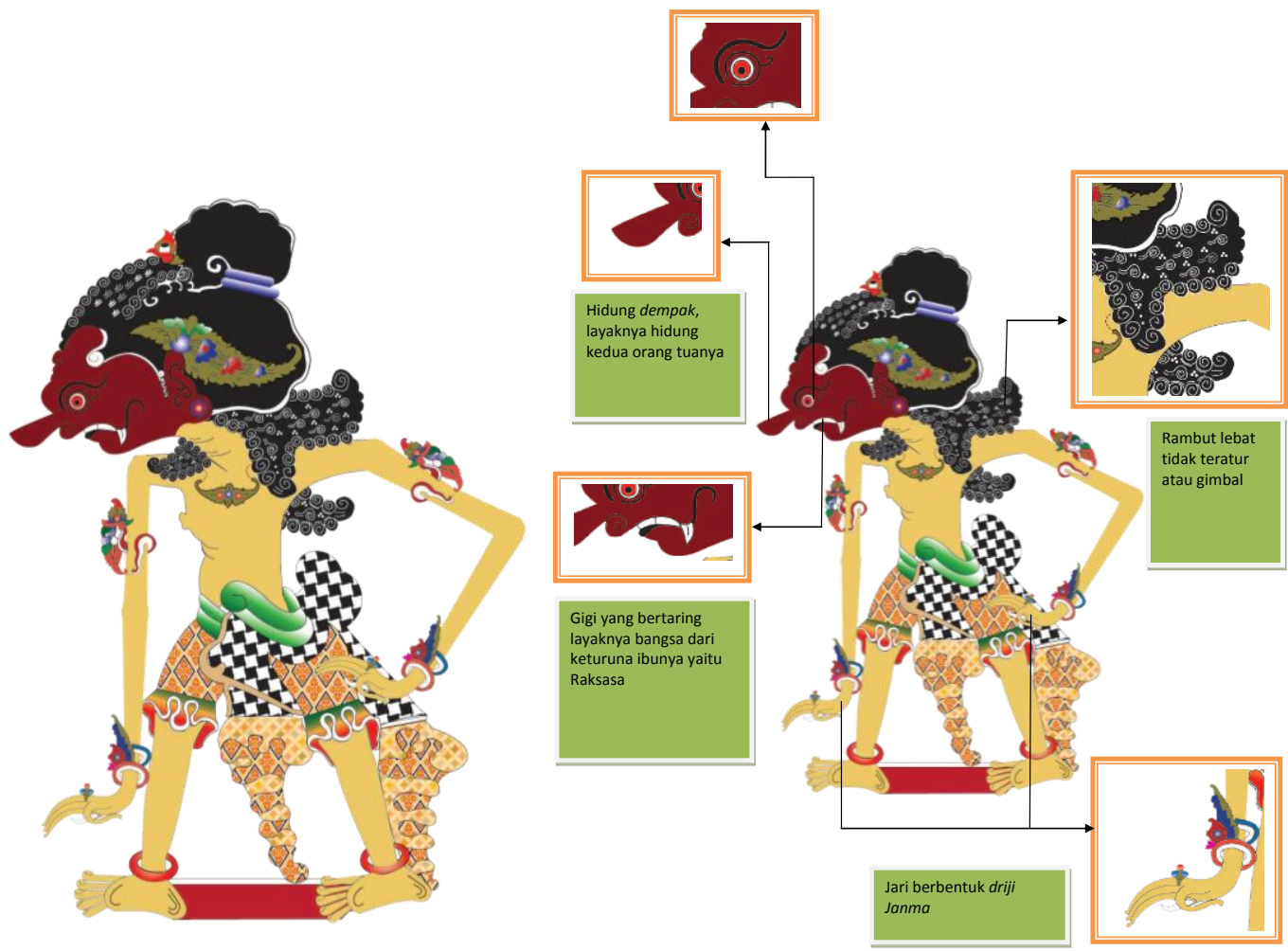

Gambar 2. Visual Bambang Tetuka Balita

(Sumber: F. Saptodewo)

Pada perancangan karakter berikutnya adalah saat Tetuka berada dalam Kawah Candradimuka sebagai pengembangan ceritanya dapat diambil perbedaan waktu di dalam dan di luar kawah Candradimuka. Berikut adalah perancangan Tetuka saat sudah menjadi remaja: 

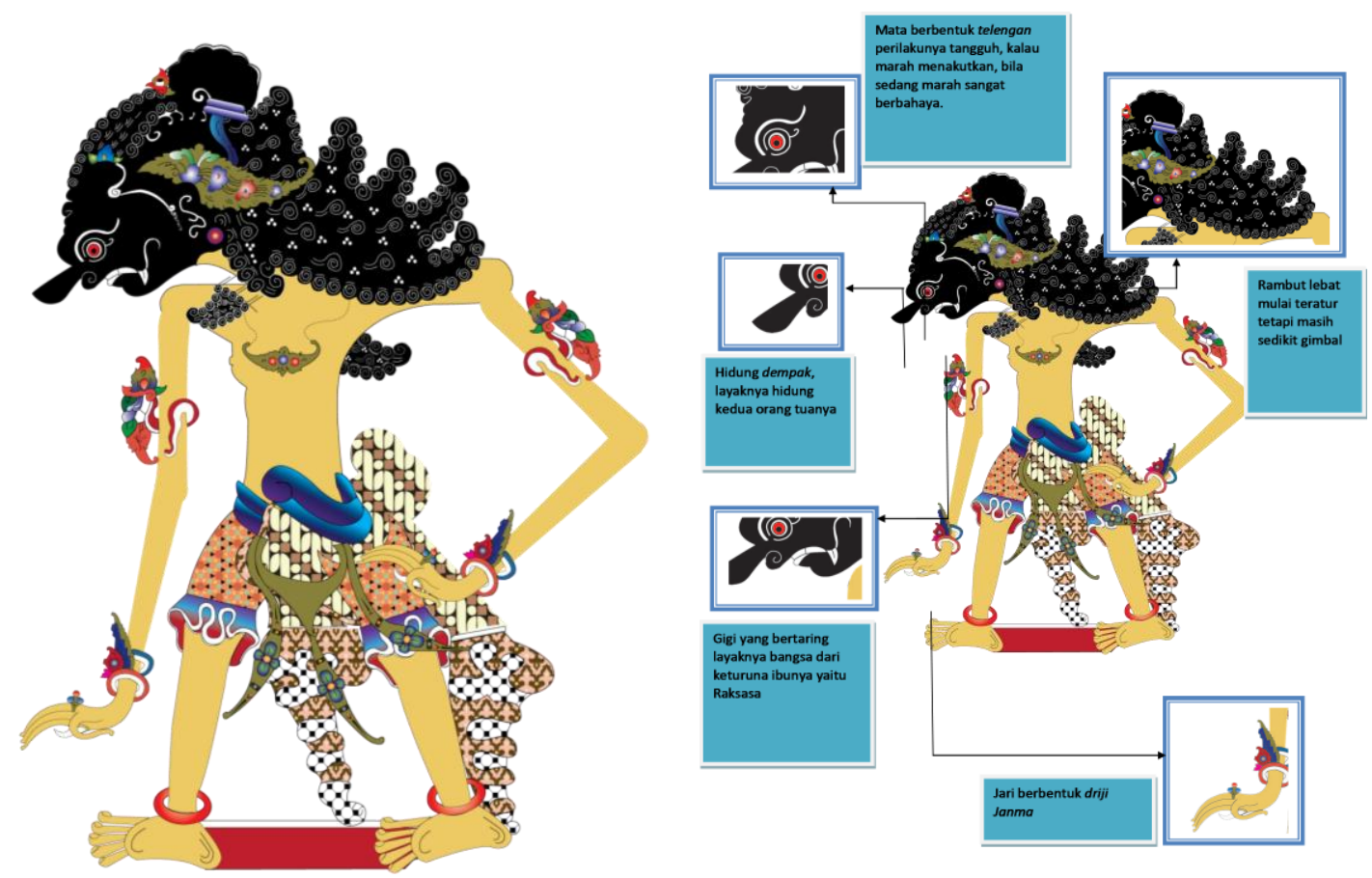

Gambar 3. Visual Bambang Tetuka Remaja

(Sumber: F. Saptodewo)

Tetuka remaja rias wajah sudah hitam karena tempaan di dalam Kawah Candradimuka, dengan fisik layaknya rakyat jelata dengan rambut gimbal tidak tertata. Konsep perancangan ini sudah diplikasikan pada Jurnal Desain Vol. 03 No. 03 Mei 2016 yang berjudul "Pengembangan Karakter Wayang Tetuka untuk Pengembangan Cerita Saat Berada di Kawah Candradimuka".

Dari beberapa rancangan terdahulu, saat Tetuka masih bayi hingga ia beranjak remaja, maka rancangan berikutnya ialah saat Tetuka beranjak dewasa dan saat ia ke luar dari Kawah Candradimuka setelah ia menyelesaikan penggodokannya di dalamnya dan menjadi seorang satria. Rancangan karakter Tetuka dewasa berbentuk menyerupai wayang Gatotkaca yang telah ada namun masih bertaring dan belum menggunakan pakaian pusaka, yaitu Caping Basunanda, Kotang Antrakusuma, dan terompah Pandakacarma dari Batara Guru. Dengan warna rias muka Tetuka yang hitam mempunyai makna simbolis kesaktian dan kemapanan hidup.

Wanda dari Tetuka dewasa berjenis thathit yang sebagai suatu gambaran atau bentuk rupa visual yang mewakili atau merefleksikan suatu suasana, emosi, atau kondisi di mana ia akan menyerang Patih Sekipu. Dalam bahasan yang lazim dikenal di dunia disain, 'wanda' dapat disetarakan dengan 'citra' (image). Penerapan 'wanda' atau 'citra' (image) pada wayang, sebagian besar hanya berkenaan dengan beberapa hal saja, yaitu: a) Sudut muka/wajah wayang (lebih menunduk atau lebih menengadah), b) Bentuk rupa wajah wayang, c) Bentuk badan wayang, d) Sudut badan wayang (lebih tegak atau lebih condong ke arah depan), e) Warna wajah (hitam, putih, 'prada', biru, merah, atau warna lainnya). Sedangkan berbagai hal lainnya, umumnya dianggap 'bisa disamakan'. Maksudnya tidak perlu ada yang diubah, meskipun 'wanda'-nya lain. 

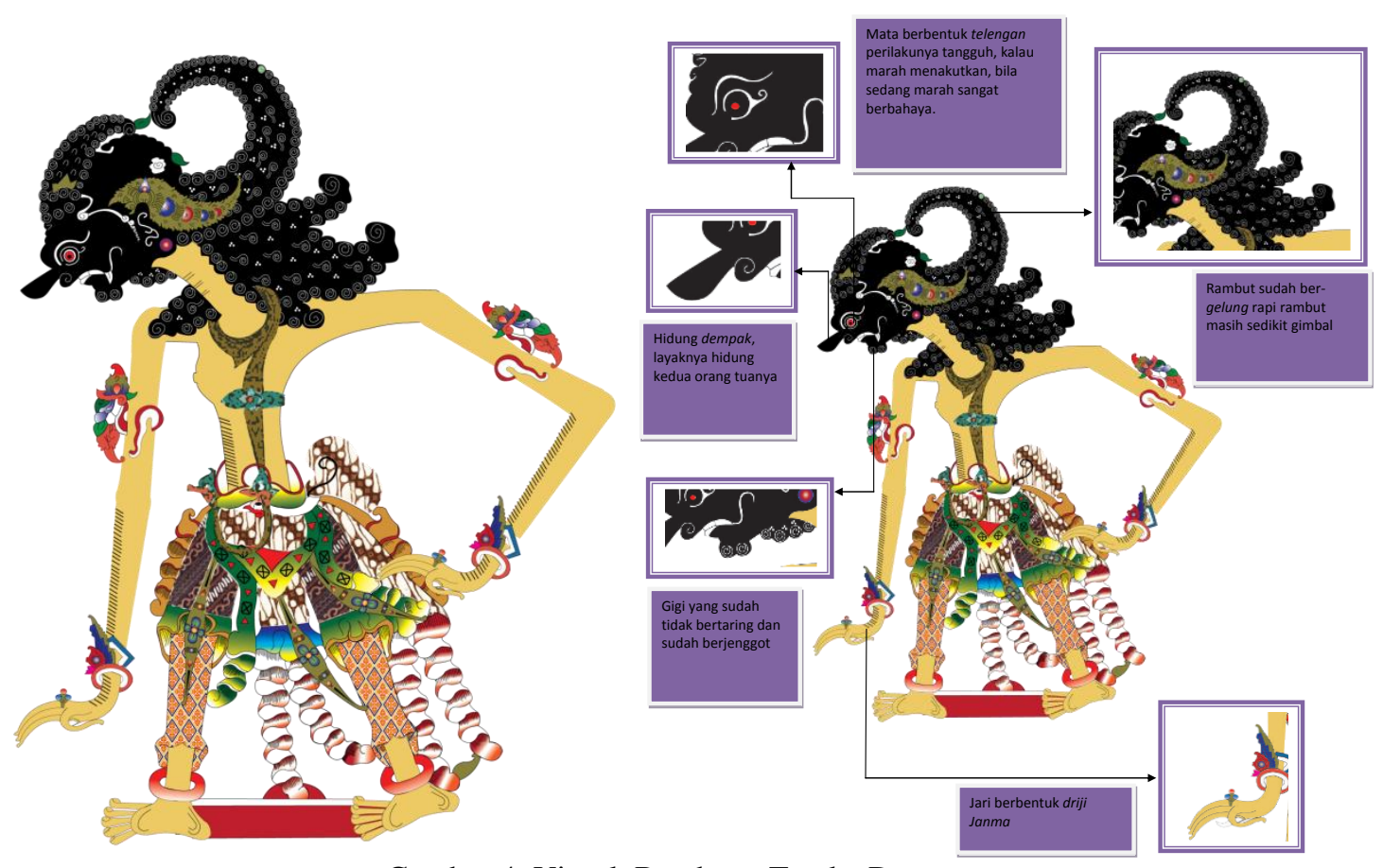

Gambar 4. Visual Bambang Tetuka Dewasa (Sumber: F. Saptodewo)

Di kurun waktu inilah kesaktian Tetuka diuji, dalam cerita setelah Tetuka ke luar dari penempaannya di Kawah Candradimuka, ia lalu bertarung dengan Patih Sekipu hingga Tetuka berhasil membunuhnya menggunakan gigitan taringnya. Untuk selanjutnya taringnya akan ditanggalkan untuk menghilangkan sifat raksasa dan mendapatkan Caping
Basunanda, Kotang Antrakusuma, dan terompah Pandakacarma dari Batara Guru dan berganti nama menjadi Gatotkaca.

Berikut adalah transformasi lengkap karakter Tetuka dari semenjak ia bayi hingga berganti nama menjadi Gatotkaca:

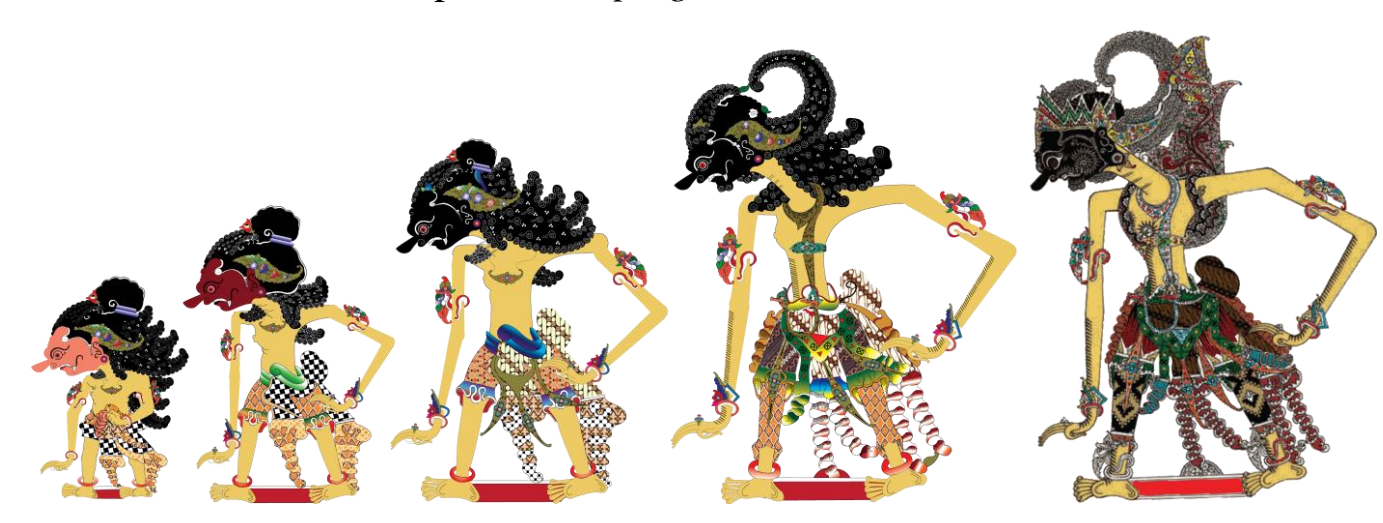

Umur 0-12 bulan Umur 1-7 tahun Umur 7-12 tahun Umur 13-20 tahun Umur 20 tahun

Gambar 4. Sketsa Transformasi Bambang Tetuka

(Sumber: F.Saptodewo) 


\section{SIMPULAN}

Perancangan karakter tokoh Tetuka saat ia telah dewasa, maka cerita pewayangan dapat dilanjutkan kembali hingga ia menjadi Gatotkaca.

Pengembangan karakter Tetuka melalui teknik digital dan teknik tatah sungging sebagai turut serta dalam pelestarian seni budaya wayang agar tidak hilang di negeri sendiri.

Karakter Tetuka dapat berkontribusi dalam penanaman moral anak bangsa dalam menghargai suatu proses pembelajaran untuk meraih kesuksesan. Dengan cerita saat Tetuka remaja

\section{DAFTAR PUSTAKA}

Hardjowirogo. (1982). Sejarah Wayang Purwa. Jakarta. Balai Pustaka.

Kartika, D. S. (2007). Estetika. Bandung: Rekayasa Sains.

Kaelola, A. (2010). Mengenal Tokoh Wayang Mahabarata, Cakrawala

Saptodewo, F. (2014). Perancangan Visualisasi Tokoh Wayang Bambang Tetuka, Jakarta. Jurnal Desain Vol. 01 No. 02
.(2015). Perancangan Bentuk Tokoh Wayang Tetuka Saat Balita, Jakarta. Jurnal Desain Vol. 03 No. 01 . (2016). Pengembangan

Karakter Wayang Tetuka untuk Pengembangan Cerita Saat Berada di Kawah Candradimuka, Jakarta. Jurnal Desain Vol. 03 No. 03

Saptodewo, F. dan Yulianto H. (2016). Buku Panduan Mata Kuliah Karakter Visual dan Anatomi Dasar

\section{Lain-Lain}

Teori desertasi estetika terapan 9 titik Ahadiat Joedawinata, Materi Perkuliahan Estetika Terapan, Jakarta, 2012

Purbasari, T, (2012). Jurnal, Kajian Aspek Teknis, Estetis, dan Simbolis Warna Wayang Kulit Karya Perajin Wayang Desa Tunahan Kabupaten Jepara. Semarang, Arty, Journal of Visual Art. 